\title{
PELAKSANAAN PENGAWASAAN TERHADAP PENGGUNAAN VISA KUNJUNGAN OLEH WARGA NEGARA ASING DI KANTOR IMIGRASI KLAS 1 TANGERANG
}

\author{
Oleh \\ Putri Hafidati*)
}

\section{Abstrak}

Negara Indonesia merupakan Negara yang memiliki Kekayaan sumber daya alam yang melimpah yang mempunyai nilai ekonomi serta keindahan panoramanya menjadi daya tarik tersendiri bagi setiap orang, tidak mengherankan apabila Indonesia merupakan salah satu titik sentral perhatian negara-negara lain baik bidang politik maupun bidang lain seperti sosial, ekonomi dan keamanan. Kenyataan ini semakin lebih mudah bagi orang asing untuk datang ke Indonesia dengan diberikannya berbagai kemudahan prosedur terutama dengan adanya opendoor policy. Dengan banyaknya orang asing yang berkunjung ke Negara Indonesia maka warga Negara asing harus memenuhi dahulu yang mana telah dibuat dalam suatu peraturan perundang-undang keimigrasian. Pada sisi lain, dalam pelaksanaan pengawasan terhadap warga Negara asing akan ada suatu kendalakendala dimana kurangnya Sumber Daya Manusia dalam penanganan warga Negara asing.

\section{Kata Kunci : Pengawasan WNA dan Penggunaan Visa}

\section{A.PENDAHULUAN}

Negara Republik Indonesia yang merupakan negara kepulauan terletak di jalur perlintasan laut Internasional menghubungkan dua samudera yaitu samudera Pasifik dan samudera Indonesia serta diapit oleh dua benua yaitu benua Asia dan benua Australia. Hal yang nyata bahwa Indonesia dengan kondisi geografisnya yang demikian merupakan jalan silang bagi jalur perlintasan pelayaran dan perdagangan Internasional. Di samping letak geografis yang sangat menguntungkan dalam hal musim jika negara lain mengenal empat musim sedangkan negara Indonesia hanya mengenal dua musim yaitu musim kemarau dan musim hujan, hal ini berpengaruh besar terhadap kesuburan alamnya. Kekayaan sumber daya alam yang melimpah yang mempunyai nilai ekonomi serta keindahan panoramanya menjadi daya tarik tersendiri bagi setiap orang, tidak mengherankan apabila Indonesia merupakan salahsatu titik sentral perhatian negara-negara lain baik bidang politik maupun bidang lain seperti sosial, ekonomi dan keamanan. Jalur ekonomi terutama menjadikan Indonesia tempat persinggahan kapal-kapal asing baik hanya sekedar melewati jalur perdagangan Internasional maupun sekedar ingin mengambil hasil kekayaan alamnya. Kenyataan ini semakin lebih mudah bagi orang asing untuk datang ke Indonesia dengan diberikannya berbagai kemudahan prosedur terutama dengan adanya opendoor policy yaitu

*) Penulis adalah Dosen Fakultas Hukum

Universitas Islam Syekh Yusuf 
politik pintu terbuka yang dilaksanakan oleh Pemerintah Hindia Belanda yaitu membuka pintu selebar-lebarnya kepada orang asing untuk masuk ke Indonesia, sehingga berbondong-bondonglah orang asing masuk ke Indonesia dengan berbagai macam tujuan, ada yang numpang hidup, sekolah, bekerja, wisata bahkan tidak sedikit yang tinggal menetap. Akibat banyak orang asing dari berbagai Ras yang diwariskan oleh Pemerintah Kolonial Hindia Belanda yang tinggal di Indonesia diantaranya adalah bangsa China, India, Arab dan lain sebagainya. Semakin lama orang asing tersebut berdiam di Indonesia akan membawa pengaruh terhadap bidang politik, budaya, ekonomi, dan keamanan. Hal inilah yang perlu dipikirkan secara serius sehingga tidak sampai menimbulkan dampak yang negatif. Setelah Indonesia Merdeka, Indonesia tidak menerapkan kebijaksanaan yang dulu yaitu kebijaksanaan "opendoor policy" yang dianggap sudah tidak sesuai lagi. Oleh karena itu Pemerintah Republik Indonesia mengeluarkan kebijaksanaan baru yaitu selective policy bahwa masuknya orang asing hanya dimungkinkan sesuai dengan kebutuhan dan memberikan manfaat bagi pembangunan Negara dan Pemerintah Republik Indonesia. Untuk mencapai masyarakat adil dan makmur, perlu digalakkan pembangunan nasional di segala bidang baik industri, perdagangan juga pariwisata sebagai salah satu usaha untuk meningkatkan devisa negara.

Kedatangan orang asing tersebut sebenarnya tidak dapat dipisahkan dengan syarat-syarat sebagai warga negara asing yang akan mengunjungi suatu negara lain baik sebagai diplomat, pedagang maupun turis. Kenyataan bahwa pesatnya perkembangan ilmu pengetahuan, teknologi dan juga transportasi memudahkan orang untuk melakukan perjalanan dari suatu negara ke negara lain. Keadaan ini harus dipandang sebagai hal yang wajar tanpa menghilangkan kewaspadaan karena tanpa disadari pasti akan membawa dampak permasalahan terutama pada lalu lintas antar negara. Dapat dipastikan tidak semua orang asing yang masuk ke Indonesia memberikan manfaat seperti yang diharapkan dalam kebijaksanaan pemerintah Negara Indonesia. Dengan demikian tugas Direktorat Jenderal Imigrasi sebagai salah satu unit pelaksanaan dan sebuah struktur bagian dari Kementerian Hukum dan Hak Asasi Manusia yang memiliki tugas pokok yang merumuskan dan melaksanakan kebijakan standarisasi teknis di bidang Imigrasi serta membentuk hukum dengan cara menerapkan Undang-Undang dan peraturan perundangan dengan masalahmasalah yang terjadi. Suatu kenyataan di Indonesia, bahwa masih banyak terdapat penyalahgunaan ijin kunjungan. Dalam menghadapi lalu lintas orang asing setiap negara dimanapun letaknya, demi menjaga keutuhan dan keamanannya, mengadakan pengawasan terhadap orang asing dengan mengeluarkan ketentuan-ketentuan yang mengatur keluar masuknya orang asing ke negara tersebut atau yang mengatur orang asing yang hendaknya bertempat tinggal di negara tersebut Melalui UndangUndang No. 6 Tahun 2011, pemerintah membuktikan kepada dunia luar bahwa pengakuan dan perlindungan hak-hak asasi manusia di Indonesia betul-betul dihargai dan dihormati. Sehingga bagi mereka yang berlalu lintas antara negara dan orang asing yang berada di Indonesia merasa terlindungi, aman dan tentram. Oleh karena itu sesuai dengan arah pembangunan, Direktorat Jendral Imigrasi harus meningkatkan kemampuan dan profesionalisme aparatnya, agar dapat mengantisipasi segala jenis tantangan, ancaman, 
hambatan dan gangguan yang timbul dari lalu lintas orang asing antar negara dan keberadaan orang asing di Indonesia.

Salah satu strategi pembangunan nasional yang dilakukan pemerintah adalah memberikan kesempatan dan kemudahan kepada para pengusaha asing untuk menanamkan modalnya di Indonesia. Untuk menarik minat para investor pemerintah memberikan kemudahankemudahan bagi perusahaan-perusahaan penanam modal asing untuk merekrut tenaga kerja ahli dari negara pemberi modal asing tersebut, tidak hanya perusahaan-perusahaan penanam modal asing saja yang diberikan kesempatan untuk merekrut tenaga ahli asing, perusahaan penanan modal dalam negeri pun bisa menggunakan tenaga ahli asing bilamana diperlukan. Dengan terbukanya kesempatan tersebut dan dilihat dari letak dan keadaan geografis Negara Republik Indonesia, maka banyak orang asing yang datang ke Indonesia untuk melakukan kegiatan di bidang usaha, perdagangan atau bisnis lainnya.

Dalam hal ini pemerintah tidak lepas dari pengawasannya untuk menjaga adanya kemungkinan-kemungkinan yang akan terjadi yang akhirnya dapat membahayakan Negara Kesatuan Republik Indonesia, maka dari itu dalam menggunakan tenaga kerja asing, perusahaanperusahaan pemberi kerja diberikan batasan-batasan seperti diatur dalam Undang-Undang Negara Republik Indonesia Nomor 13 Tahun 2003 Tentang Ketenagakerjaan.

Keimigrasian pada dasarnya dapat dirumuskan sebagai hal ikhwal lalu lintas orang yang masuk atau keluar wilayah Negara Republik Indonesia dan pengawasan terhadap orang asing di wilayah Negara Kesatuan Republik Indonesia. ${ }^{1}$

1 Undang-Undang No. 6 Tahun 2011 Tentang Keimigrasian, Pasal 1 ayat (1).
Dari pengertian tersebut dapat dinyatakan bahwa :

1. Lapangan (Objek) Hukum dari Keimigrasian adalah : Lalu Lintas dan Pengawasan Keimigrasian.

2. Subjek Hukum dari hukum Keimigrasian adalah : Orang yang masuk atau keluar Wilayah Negara Republik Indonesia, yang dimaksud dengan "Orang" dalam pengertian ini tidak hanya Warga Negara Indonesia saja, tetapi juga orang Warga Negara Asing. ${ }^{2}$

Visa adalah izin tertulis yang diberikan oleh pejabat yang berwenang pada Perwakilan Republik Indonesia atau di tempat lainnya yang ditetapkan oleh Pemerintah Republik Indonesia yang memuat persetujuan bagi orang asing untuk masuk dan melakukan perjalanan ke wilayah Negara Republik Indonesia. Visa terdiri dari berbagai macam yaitu Visa Singgah, Visa Singgah Saat Kedatangan, Visa Kunjungan, Visa Kunjungan Kolektif, Visa Kunjungan Saat Kedatangan, Visa Kunjungan Usaha beberapa kali perjalanan, dan Visa Tinggal Terbatas.

Pada kenyataannya seperti apa yang kini sering dibicarakan pada media massa maupun pada media elektronik tentang banyaknya orang asing yang melakukan pelanggaran-pelanggaran keimigrasian, mulai dari izin tinggal melebihi masa waktu yang ditentukan (over stay) sampai kepada penyalahgunaan izin kerja atau lebih dikenal dengan penyalahgunaan visa, yang dikeluarkan oleh Departemen Tenaga Kerja dan Transmigrasi. Namun bukan hanya itu saja, media juga selalu memberikan kritikan-kritikan kepada Imigrasi dalam hal mengatasi masalah tersebut.

2 Imam Santoso, Perspektif_Imigrasi Dalam Pembangunan Ekonomi $\bar{d}$ an Ketahanan Nasional, (Jakarta: Universitas Indonesia, 2004), hal. 25 
Atas dasar pentingnya pengawasan terhadap tenaga kerja asing serta untuk mengetahui sejauh mana pelaksanaan pengawasan yang dilakukan oleh imigrasi terhadap tenaga kerja asing yang berada di Wilayah Negara Kesatuan Republik Indonesia khususnya di Wilayah Kantor Imigrasi Klas I Tangerang. Sehubungan dengan maksud dilakukannya pengkajian terhadap masalah tersebut:

1. Bagaimanakah pengaturan prosedur pemberian visa kunjungan bagi Warga Negara Asing di Indonesia?

2. Kendala-kendala yang dihadapi dalam pelaksanaan pengawasan terhadap penggunaan Visa On Arrival tersebut?

\section{B. PEMBAHASAN}

\section{Pelaksanaan Pemberian Visa on Arrival Pada TPI Kelas I Khusus Soekarno-Hatta}

Sebagaimana diketahui bahwa untuk masuk dan melakukan perjalanan ke suatu negara harus memiliki izin dari negara yang bersangkutan yang disebut visa dan Indonesia termasuk dalam negara yang menganut keharusan untuk memiliki visa. Bahwa setiap orang asing yang masuk ke wilayah Indonesia wajib memiliki visa, terkecuali bagi negara yang berdasarkan Keputusan Presiden Republik Indonesia Nomor 21 Tahun 2016 tentang Bebas Visa Kunjungan Singkat yang dibebaskan dari keharusan memiliki visa.

Hal ini sesuai dengan ketentuan yang terdapat dalam Undang-Undang Nomor 6 tahun 2011 tentang keimigrasian pasal 8 (delapan) yang dikecualikan dari kewajiban memiliki visa adalah :

1. orang asing warga negara dari negara yang berdasarkan Keputusan Presiden tidak diwajibkan memiliki visa;

2. orang asing yang memiliki Izin Masuk Kembali;
3. kapten atau nakhoda dan awak yang bertugas pada alat angkut yang berlabuh di pelabuhan atau mendarat di bandar udara di wilayah Indonesia;

4. penumpang transit di pelabuhan atau bandar udara di wilayah Indonesia sepanjang tidak keluar dari tempat transit yang berada di daerah tempat pemeriksaan imigrasi.

Dalam rangka meningkatkan arus kedatangan wisatawan mancanegara ke Indonesia, sehingga perlu penambahan pemberian fasilitas Visa on Arrival bagi warga negara dari beberapa negara tertentu untuk memasuki wilayah Republik Indonesia. Visa on Arrival diberikan oleh pejabat imigrasi yang bertugas di tempat pemeriksaan imigrasi tertentu yaitu:

1. Pelabuhan udara yaitu :

a. Kualanamu di Medan

b. Sultan Syarif Kasim II di Pekan Baru

c. Minangkabau di Padang

d. Soekarno-Hatta di Jakarta

e. Juanda di Surabaya

f. Ngurah Rai di Bali

g. Sam Ratulangi di Manado

h. Halim Perdana Kusuma di Jakarta

i. Adisucipto di Yogyakrta

j. Adisumarno di Surakarta

k. Selaparang di Mataram

1. Sepinggan di Balikpapan

m.Hasanuddin di Makasar

n. El Tari di Kupang

o. Hang Nadim di Batam

p. Ahmad Yani di Semarang

q. Husein Sastranegara di Bandung

2. Pelabuhan laut yaitu :

a. Sekupang, Batu Ampar, Nongsa, Marina, Teluk Senimba dan Batam Center di Batam

b. Bandar Bintan Telani Lagoi dan Bandar Sri Udana Lobam di Tanjung Uban

c. Belawan di Belawan

d. Sibolga di sibolga

e. Yos Sudarso di Dumai

f. Teluk Bayur di Padang 
g. Tanjung Priok di Jakarta

h. Tanjung Mas di Semarang

i. Padang Bai dan Benoa di Bali

j. Soekarno-Hatta di makasar

k. Jaya pura di Jayapura

1. Bitung di Bitung

m.Tanjung Balai Karimun di Tanjung Balai Karimun

n. Tenau di Kupang

o. Pare-pare di Pare-pare

p. Maumere di Nusa Tenggara Timur dan

q. Sri Bintan Pura di Tanjung Pinang

Pemberian Visa On Arrival diberikan langsung pada saat orang asing tersebut tiba atau mendarat di Indonesia, karena pada dasarnya Visa on Arrival merupakan kemudahan yang diberikan oleh pemerintah Republik Indonesia kepada orang asing di bidang keimigrasian.

Pemberian Visa on Arrival dapat dilakukan apabila orang asing tersebut memenuhi persyaratan yang telah ditentukan. Adapun persyaratan untuk permohonan Visa on Arrival adalah sebagai berikut;

1. Kartu kedatangan/keberangkatan yang telah diisi

2. Paspor kebangsaan yang sah dan masih berlaku minimal 6 (enam) bulan pada saat tiba di Indonesia

3. Bukti pembayaran biaya visa sesuai ketentuan yang berlaku

4. Tidak termasuk dalam daftar penangkalan.

Biaya Visa on Arrival ditetapkan sesuai dengan Peraturan Pemerintah Republik Indonesia Nomor 10 Tahun 2015 Tentang Perubahan Atas Peraturan Pemerintah Nomor 45 Tahun 2014 Tentang Jenis dan Tarif Atas Jenis Penerimaan Negara bukan pajak yang berlaku pada Kementerian Hukum dan Hak Asasi Manusia Republik Indonesia. Adapun biaya yang dikenakan adalah sebesar:

1. US\$ 15 untuk 7 (tujuh) hari

2. US\$35 untuk 30 (tiga puluh) hari
Adapun prosedur pemberian Visa On Arrival adalah disesuaikan dengan Petunjuk Pelaksanaan Direktur Jenderal Imigrasi yang dituangkan dalam memberikan persyaratan kepada pemohon Visa on Arrival ini sebagaimana disebutkan dalam pasal 2 yaitu :

1. Pemohon untuk memperoleh Visa Kunjungan Saat Kedatangan diajukan langsung oleh yang bersangkutan kepada pejabat imigrasi di loket Visa Kunjungan Saat Kedatangan pada Tempat Pemeriksaan Imigrasi dengan melampirkan persyaratan yang telah ditentukan.

2. Pemohon Visa Kunjungan Saat Kedatangan wajib mengisi kartu kedatangan/keberangkatan yang berfungsi sebagai formulir permohonan.

3. Pemohon Visa Kunjungan Saat Kedatangan membayar bea visa sesuai dengan ketentuan.

Selanjutnya dalam pelaksanaan di lapangan (Bandara Internasional Soekarno-Hatta), pemohon Visa on Arrival tersebut harus mengikuti beberapa tahapan/langkah, sebagai berikut :

1. Tahap pertama, pemohon membeli voucher visa pada bank dan membayar tunai sesuai dengan izin tinggal yang diinginkan. Selanjutnya kepada pemohon diberikan Visa on Arrival receipt (kwitansi pembayaran Visa on Arrival).

2. Tahap kedua, setelah pemohon membeli voucher dan membayarnya pada bank, selanjutnya mengajukan visa pada Immigration Visa Office (kantor Visa Imigrasi) yang bersebelahan dengan kantor Bank. Dimana pada kantor visa ini orang asing wajib menyerahkan paspor, receipt VOA Bank, dan Arrival/ Departure Card.

3. Tahap ketiga, petugas imigrasi yang berada di kantor visa imigrasi melaksanaan hal sebagai berikut :

a. Memeriksa kebenaran receipt VOA dari Bank dengan menggunakan 
alat pendeteksi sekaligus memasukkan nomor bukti pembayaran.

b. Memeriksa keabsahan paspor, yaitu melihat tanggal berlaku paspor, halaman visa yang masih kosong, dan memeriksa apakah foto pada paspor sama dengan wajah si orang asing tersebut.

c. Selanjutnya menggesek bar code paspor ke Machine Readable Passport (MRP) untuk menampilkan identitasnya pada layar monitor komputer dan mengisi secara manual jika tidak memiliki barcode passport serta menyimpannya ke hardisk.

d. Stiker Visa on Arrival akan keluar dari mesin printer yang berisi ketentuan tentang Visa on Arrival dan selanjutnya menscan nomor visa ke komputer.

e. Menempel stiker visa tersebut ke halaman visa.

f. Mencabut nomor visa dan menempelnya ke receipt VOA serta menyimpannya untuk administrasi.

Selanjutnya setelah orang asing tersebut mendapatkan Visa On Arrival yang sudah ditempel pada paspornya, yang bersangkutan harus menuju ke konter imigrasi untuk mendapatkan pemeriksaan keimigrasian sebagai berikut :

1. Pejabat imigrasi memeriksa surat perjalanan yang bersangkutan dan mencocokkannya dengan pemegangnya dengan ketentuan bahwa surat perjalanan tersebut masih berlaku minimal 6 bulan sekurang-kurangnya.

2. Memeriksa pengisian kartu kedatangan dan keberangkatan dan mencocokkannya dengan data pada surat perjalanannya.

3. Memeriksa daftar cegah tangkal

4. Memeriksa Visa on Arrival yang bersangkutan
5. Memeriksa tiket untuk kembali ke negara asalnya serta uang jaminan selama berada di Indonesia jika perlu. Apabila syarat-syarat di atas telah dipenuhi, maka pejabat imigrasi yang di kounter akan menerakan cap/stempel visa on arrival pada halaman paspornya dan menentukan lama tinggalnya 7 atau 30 hari.

Bentuk Visa on Arrival adalah berupa stiker berbentuk segi empat berukuran 4 $\mathrm{cm} \times 3,5 \mathrm{~cm}$. Isi cap pada Visa on Arrival berupa catatan-catatan dalam Bahasa Indonesia dan Bahasa Inggris seperti:

1. Imigrasi Indonesia

2. Tempat Pemeriksaan Imigrasi

3. On Arrival Pass

4. Permitted to enter and remain

5. Kolom tanggal

6. In Indonesia for 7 (seven) / 30 (thirty) days

7. From date shown above

8. Not extendable

9. Dasar hukum pemberian izin masuk saat kedatangan

10. kode cap

11. Dua bintang menutupi not extendable

Visa on Arrival dapat diperpanjang atas persetujuan Direktur Jenderal Imigrasi dalam hal terjadi :

1. bencana alam di tempat pemegang Visa Kunjungan Saat Kedatangan berada; atau

2. kecelakaan atau sakit terhadap pemegang Visa Kunjungan Saat Kedatangan

Tetapi Visa on Arrival ini tidak dapat dialihstatuskan menjadi izin keimigrasian lainnya.

\section{Kendala yang Dihadapi Dalam Pelaksanaan Pengawasan Terhadap Penggunaan Visa on Arrival}

Berapa kendala-kendala yang sering ditemui pada saat pemberian Visa on Arrival adalah sebagai berikut : 
1. Apabila beberapa pesawat tiba secara bersamaan dan penumpang turun secara bersamaan pula, sehingga akan menimbulkan antrian penumpang yang panjang baik penumpang yang memohon visa pada kantor visa dan juga konter imigrasi, sementara jumlah pegawai imigrasi yang melayani permohonan Visa on Arrival dan komputer yang ada terbatas.

2. Pada pelaksanaannya petugas imigrasi di Bandara Internasional Soekarno-Hatta dalam melakukan pemeriksaan keimigrasian terhadap orang asing tersebut memerlukan dua (2) tahap, yaitu yang pertama pada saat ia melakukan permohonan pada kantor Visa on Arrival dan yang kedua pada konter pemeriksaan imigrasi yang digabung dengan penumpang lain. Dengan adanya dua tahapan ini maka waktu yang dibutuhkan lebih lama dan tenaga petugas imigrasi yang ada juga lebih banyak diperlukan.

3. Sistem komputerisasi Visa on Arrival yang saat ini belum online atau terintegrasi, sehingga data yang masuk dari orang asing pengguna Visa on Arrival tidak dapat langsung diterima atau diakses baik oleh pusat dalam hal ini Direktorat Jenderal Imigrasi maupun Kantor Imigrasi Kelas I Khusus Soekarno-Hatta sehingga data yang masuk menjadi telat dan tidak akurat karena hanya didasarkan pada data manual.

4. Kurangnya pegawai imigrasi dan peralatan komputer juga banyak yang rusak menyebabkan palayanan menjadi tidak optimal. Hal ini banyak disebabkan karena tidak tersedianya biaya pemeliharaan perangkat komputer tersebut dan tidak adanya pelatihan bagi seorang pejabat imigrasi yang akan bertugas pada pelabuhan internasional.
5. Bentuk visa yang berbentuk stiker dan ukurannya cukup besar sering dikeluhkan oleh orang asing terutama orang asing yang melakukan kegiatan bisnis dan pariwisata di Indonesia karena menghabiskan halaman paspor sedangkan mereka sering keluar.

Dalam penanganan pengawasan warga negara asing masih banyaknya jalan pintas di wilayah Indonesia. Hal itu bisa dimasuki lantaran tidak adanya pengamanan wilayah perbatasan. Persoalan ini menjadi suatu masalah di Negeri ini, tidak ada instansi yang menjaganya. Maka sering digunakan seperti penyelundupan Narkoba dan kejahatan lainnya sehingga tidak bisa dipantau. Untuk konsep di Indonesia saat ini belum sepadan antara geografis dengan struktur organisasi di pengamanan. Misalkan jumlah pulau Di Indonesia 17.000 sedangkan jumlah pegawai Imigrasinya hanya 7.000 personil.

Selain itu, terkait sistem pengamanan di Undang-Undang imigrasi masih menggunakan Undang-Undang yang lama sehingga sulit untuk diterapkan dengan perkembangan lintas batas saat ini.

\section{PENUTUP}

Mengenai Tinjauan Pemberian Visa on Arrival Terhadap Peningkatan Wisatawan Mancanegara Pada Kanim Kelas I Khusus Soekarno-Hatta (Bandara Internasional Soekarno-Hatta), maka dapat ditarik kesimpulan sebagai berikut :

1. Bahwa kebijakan Visa on Arrival yang merupakan terobosan penting di bidang keimigrasian sebagai pengganti dari Bebas Visa Kunjungan Singkat (BVKS) yang pada mulanya mendapat pertentangan khususnya dari dunia pariwisata karena dikhawatirkan dapat menurunkan wisatawan mancanegara ke Indonesia pada kenyataannya tidak terbukti. Hal ini 
dibuktikan dengan perbandingan orang asing yang masuk ke Indonesia pada tahun 2017 Sampai dengan tahun 2018 sejak diberlakukannya Visa on Arrival, justru mengalami peningkatan yaitu dari 5.539.791 wisatawan asing pada tahun 2017 menjadi 6.127.437 pada tahun 2018 . Karena pada dasarnya yang terpenting bagi wisatawan asing adalah meningkatkan mutu pelayanan terhadap turis yaitu faktor keamanan dalam negeri, promosi, kenyaman, kebersihan, perilaku masyarakat yang ramah tamah lebih menentukan kenaikan jumlah wisatawan. Dengan diberlakukannya Visa on Arrival tersebut telah turut meningkatkan wisatawan asing ke Indonesia, sebab dengan adanya pemberian Visa on Arrival tersebut memudahkan dan memperlancar orang asing masuk dan melakukan perjalanan ke Indonesia.

2. Seiring dengan peningkatan wisatawan asing yang masuk ke Indonesia dengan menggunakan Visa on Arrival akan turut pula kendala-kendala yang dihadapi dalam pelaksanaan pengawasan terhadap penggunaan visa kerja apabila warga negara asing tiba dengan waktu yang bersamaan sehingga sangat tidak terjangkau dengan minimnya personil imigrasi dalam suatu pemeriksaan.

\section{DAFTAR PUSTAKA}

Undang-Undang No. 6 Tahun 2011 Tentang Keimigrasian

Imam Santoso, Perspektif_Imigrasi Dalam Pembangunan Ekonomi dan Ketahanan Nasional, (Jakarta: Universitas Indonesia, 2004),
Peraturan Pemerintah Nomor 45 Tahun 2014 Tentang Jenis dan Tarif Atas Jenis Penerimaan Negara bukan pajak yang berlaku pada Kementerian Hukum dan Hak Asasi Manusia Republik Indonesia

Keputusan Presiden Republik Indonesia Nomor 21 Tahun 2016 tentang Bebas Visa Kunjungan 